\title{
SPECIFYING THE LIFE CYCLE PHASES OF REGIONAL INNOVATION CLUSTERS
}

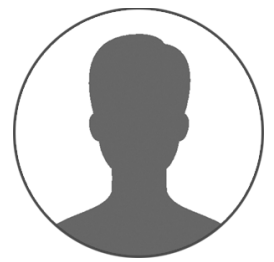

Article history:

Received 6 December 2018

Received in revised form

26 December 2018

Accepted 17 January 2019

Translated 18 February 2019

Available online 29 March 2019

JEL classification: R11, R12

Keywords: life cycle,

regional innovation cluster, cluster development, cluster performance phases

\author{
Denis A. NIKOLAEV \\ Kazan Innovate University named after V.G. Timiryasov (IEML), Kazan, Republic of Tatarstan, \\ Russian Federation \\ dnicolaev92@gmail.com \\ https://orcid.org/0000-0002-8133-2706
}

\begin{abstract}
Subject The article discusses the creation and operation of regional innovation clusters in the Russian economy, primarily, in terms of their life cycles.

Objectives Analyzing views of other scholars, I propose an original approach to development phases of regional innovation clusters and determine possible ways for the region and regional innovation cluster to integrate throughout phases.

Methods The research uses the abstraction and logic method.

Results I suggest complementing the traditional linear sequence of life cycle phases with alternative scenarios. The traditional list of the phases, which most scholars point out, is supplemented and described in more details, inter alia, by highlighting interim phases and giving account of key actions performed within the analyzable process. I discovered new phases of regional innovation clusters' life cycle, such as the preliminary preparation in pursuit of synergy, adaptation, reassumed development. New interim phases include the pre-synergistic growth, synergistic growth, storming, decay, mutation. I also examine the integration of the region and regional innovation cluster at each interim phase.

Conclusions and Relevance All alternative development scenarios spring from points at which the evolution of regional innovation clusters may vary. Strategic decisions or crucial solutions made at such points contribute to further growth (or decline) in the cluster. The preliminary preparation, creation, adaptation, development are the most important phases when the region has to be as much involved as possible at the variability points of its evolution. The cluster demonstrates the highest productivity when it reaches the maturity phase during storming or after it reassumes the development, being mature.
\end{abstract}

The editor-in-charge of this article was Irina M. Vechkanova Authorized translation by Irina M. Vechkanova

Currently, there are dozens of regional innovation clusters in Russia. The USA is the home for the largest number of clusters worldwide (380 clusters [1]), with the predominance of regional innovation clusters. However, the Russian innovation clusters evolve not so effectively as they could because they do not emerge naturally but rather represent the combination and venture of already operational companies. In the mean

${ }^{\dagger}$ For the source article, please refer to: Николаев Д.А. Уточнение этапов жизненного цикла региональных инновационных кластеров // Национальные интересы: приоритеты и безопасность. 2019. Т. 15. № 2. C. 343-358. URL: https://doi.org/10.24891/ni.15.2.343 time, in the current crisis situation [2, 3] it seem too unrealistic to see them spring out of nowhere in the Russian market. That is the reason for defining phases which would aggregate positive aspects of both processes and accommodate for the specifics of regional innovative clusters. Under the current economic circumstances [4-6], it is necessary to examine the issue and fins feasible ways to integrate the regional innovative cluster into the regional economy and clarify what situations will require the regional authorities' involvement as much as possible 
and which cluster may be less burdensome and more useful for the region 1 .

What it is important to understand for the stewardship of the regional innovation cluster is the reciprocal role the region and cluster play for one another at each of the phases.

Scholars have identified the following cluster development phases:

1) emergence of the cluster creation initiative;

2) formation of the cluster;

3) development of the cluster;

4) growth in the cluster attractiveness;

5) maturity;

6) formulation and acceptance of the cluster development strategy;

7) decline and dissolution of the cluster;

8) transformation.

Fig. 1 outlines such a model. The statements below appear to constitute the general drawbacks of the concept.

1. Development phases are linear. That is, each phase begins after the completion of the previous one.

2. A group of entities united by a certain principle is a cluster as is.

Referring to views of other authors and pinpointing the principles which will suit for the further development and additional elaboration, I model life cycle phases of regional innovative clusters.

D. Katzenbach and S. Smith provide their vision of project team building [7]. Drawing upon the previous

\footnotetext{
${ }^{1}$ In the Russian Federation, the majority of clusters are evolving. In particular, IT clusters in the Perm Krai (founded in 2013), Penza Oblast (2013), ICT cluster in the Rostov-on-Don cluster, local innovation cluster of navigational, telematic and geoinformation systems (GLONASS/GPS) in the Orel Oblast (2015), IT cluster in the Smolensk Oblast (2015), IT cluster in the Novgorod Oblast (2014). Few clusters are mature. These are the IT cluster in the Republic of Tatarstan (2015), Siberian Science Polis Research and Production Cluster (2013), Development of Information Technology, Radioelectronics of Mechanical Engineering, Communication Facilities and Information and Communications of Sain Petersburg (1999). However, the above cluster cannot pass the maturity phase. Clusters may be so slow in their development because their preliminary phases were based on low quality analytics, neglecting what conditions a cluster lives in during the adaptation phase. Furthermore, the reason may be that the region and regional innovation cluster had controversial reciprocal expectations, thus cooperating in an erroneous and inappropriate way.
}

research, the authors presume that all teams undergo the same steps during their formation (Fig. 2). At the initial step, a group of people is convened, with each member demonstrating a certain performance level. It is totally equivalent to the level which is denoted as a single leader group. People set up contacts and rearrange processes subsequently. General productivity hits its lowest level as an example of a quasi-team. At this point of time, communications and processes become a supportive factor for the team, while the team building advantages also starts generating positive effect. The team's performance is booming. At a certain point of time, the (potential) team works as effectively as people did before their convention. Continuing their work, the team reaches their normal performance indicators, which should be higher than the total of some individual members [7].

Similarly, we review the productivity of a cluster when it is set up and developed. As mentioned above, at the initial phase, the cluster is made up of pioneering companies, which have already showed some productivity and performance. Total productivity is denoted as 1 in Fig. 3. The productivity may subsequently go down, with the lowest level being plotted as 2. The decline stems from new ties within the cluster, developments in logistics, new processes and strategies within the company. I call this interim phase the adaptation period of the innovation cluster development. A.A. Kireeva pays great attention to the creation and development of regional innovation clusters in her research [8], however saying nothing why such clusters perform worse afterward.

After the cluster hits the lowest level, its productivity assumes to rise. In the mean time, I should point out the period starting from the lowest level of productivity up to the identical productivity of companies (before they were combined into the cluster) and denote it as the interim phase of pre-synergistic cluster development. It is important to phase out the period between points 1 and 3 in Fig. 3 because it helps make such a decline less sharp if such periods of the cluster operations are recognized. D.V. Frolkin revealed the importance of such prior preparation but he did not mention that the synergy of the future cluster constituents should be preliminarily raised as well [9]. As a matter of fact, the preparation process suggested by D.V. Frolkin is a line between point 0 and 1 (Fig. 3) running side-by-side the $x$-axis. I should admit I share this idea. 
The section depicted with line $0-1$ is the phase of the cluster origination. During the phase, the cluster creates conditions which determine to what extent point 2 descend. In this case, the region has no direct impact on the pioneering companies but it can begin preparing the cluster infrastructure. This is the cluster planning phase when the cluster is evaluated in terms of feasibility and reasonableness, its functions are analyzed and forecasted, respective strategy is outlined, regional budget is formed, cluster structure is described. The optimization of logistics, composition of residents determine the level of point 2 . During the phase, it means that the productivity of the regional innovation cluster remains the same without any dynamics. The reason is that the same interaction processes take place as at the phase of pioneering companies, while the integration processes involves only some employees of the companies (management, analysts and region's representatives) who condition the structure so as to make the transition as soft as possible. Therefore, the more profound preparation for the development at the origination phase, the higher the position of point 2 .

After point 3 is passed (here the cluster becomes identical to total productivity of standalone companies), the graph goes toward point 4, where the cluster reaches the performance indicators planned during the creation phase. Starting from this moment, the cluster comes into its maturity phase. I call the interim phase, which takes place between points 2 and 4, a growth. The section between points 4 and 5 corresponds with the stabilization and transition to the maturity phase when the productivity cannot grow as actively as at the growth phase. Passing through this section, the growth gradually slows down, and the cluster sees the productivity stabilize at a certain level. This happens when some factors (market structure, active participation of the region, interaction within the cluster) get balanced. It is noteworthy that the phase may start when the productivity is different from the planned one, being lower. In this case, it is easier to push it to the planned trajectory than at the maturity phase due to the inertial motion.

I should note that the section between points 1 and 3 appears to be the most complicated phase of the relationships between the region and regional innovation cluster. The productivity of the cluster is minimum then, however, the demand for regional aid is maximum. Passing through this section, the region should assist the cluster as it used to so as to derive the benefit in the future as it planned. It should help the cluster create the infrastructure, raise necessary funds and establish external contacts of the cluster. The integration of the real and financial sector of the economy is studied in the research referred to herein [10]. It is important to remember that the innovation sector needs a substantial aid from the State at the initial phase of investment.

I consider the points at which the cluster may have alternative rising or falling scenarios as points of the evolutionary variability of the regional innovation cluster. Such points may have different sources and strongly depend on the phase when they spring.

Although taking place rarely, there exists another economic situation (though A.A. Zaika tags it typical [11]) when the cluster reaches some maturity phase after the origination and development phases are passed. During the protracted maturity phase, the productivity is permanent (or fluctuates within an insignificant range). I presume, it is impracticable to attain a level and stick to it for a long period of time. Abstaining from further development and growth, many issues and challenges may pile up, thereby leading the cluster to a decay, namely:

- changes in the demand for products;

- logistic troubles;

- cessation or decline in external interactions;

- declining interest of the regional authorities in the cluster.

This is the reason why the maturity phase may end rather quickly and turn into the decay if the cluster shifts from the development to maturity without striving to improvements. I suggest tagging the interim phase preceding such decay as stagnation. In Fig. 4, the dash-and-dot line denotes a curve which emerges in the real life situation when the cluster attempts to level off during the maturity phase. The dash line shows a graph proposed by V.V. Spitsyn [12]. V.V. Spitsyn gives the fullest account of the maturity phase model. Hence, I rely upon this description to further unfold it and adjust for real factors.

Therefore, there should not be an even and stable level (from point $A$ to point $C$ ) during the maturity phase. This opinion diverges from the previous models implying that the cluster evolves (this process denoted as the section from $A$ to $D$ - the continuous improvement process) or stagnates (starting from point B to point F). 
It is evident that it is impossible to make the cluster grow as it did during the development phase. However, some improvements are still practicable.

In regional innovation clusters, storming phases can stem from various factors. The factors have both regional and innovation roots:

- cancellation of funding or region's aid to the cluster due to changes in the regional development priorities or overall decline in the region;

- alterations in the geopolitical position of the region (for example, D.A. Rovin gives an example when the Dalian cluster was formed after the Chinese government decided to open the region for foreign investors in 1984 [13]).

To address the above issues and put an end to storming, I suggest undertaking the following steps:

- determining the significance of the cluster development as part of the interaction with the regional authorities;

- adapting to the available financial resources;

- adapting to the market requirements;

- accommodating the market for existing needs or requirements.

The return to development deserves a special mention since it is an alternative interim phase of maturity. The process sees an explosive growth of the cluster upon its maturity. This may happen at the evolutionary variability point due to the following reasons:

1) successful elimination of strategic difficulties;

2) revolutionary breakthroughs driving the cluster to a new market;

3) intense aid from the region during the maturity phase.

Fig. 5 depicts the interim phase between points $A$ and $B$.

The cluster steps into the last phase of its life cycle, which springs from its evolutionary variability point, starting to decline. The decline has three alternative scenarios, i.e. reemergence, transformation or dissolution. The reemergence and transformation are similar in terms of structure but still have some distinctions and virtually represent the rearrangement. As per the first scenario, the cluster undergoes so dramatic changes that the cluster's indicators plummet from the very beginning (down to point 1. See Fig. 3). It is worth mentioning that the appropriate and correct strategy will help the cluster survive, passing all the phases of development.

Transformation also entails a drop, though not a drastic one. Transformation deeply reshapes the structure of the cluster. The reemergence and transformation of the cluster make it more viable since it skips the creation phase, while the existing infrastructure and expertise allow to reduce the duration of the development phase. The cluster dissolution is a process when the cluster terminates to exist. In Fig. 6, solid and dash-and-dot line depict the dissolution of the cluster. The dashed line means the reemergence, with the dotted line indicating the transformation.

Transformation and reemergence can take place in the following cases:

1) the cluster is in deep recession (causes are the same as for the storming phase), which is overcome through transformation;

2) the cluster decides to adapt to the frequently changing market of innovation;

3) the region forces the cluster to undergo a deep transformation.

The cluster dissolution is an alternative to transformation and reemergence. There are two absolutely different approaches to dissolve the cluster.

1. The cluster preserves the same composition of companies which reside in it (line A-C in Fig. 6);

2. Companies of the cluster are dissolved (line A-D in Fig. 6). This scenario is probable when multiple clusters go bankrupt.

What makes both options different is the ultimate point of the productivity. In the first case, the productivity point will considerably go down (down to point C). As a rule, the level will anyway remain higher than that before the formation of the cluster. The reason is that research and advantages of standalone companies, which they created joining the cluster, contributed to their competitive advantage. In the second case, mass bankruptcy of companies will bring the productivity down to zero. In Fig. 6, the continuous line denotes the dissolution of the cluster and residing companies, dashand-dot line indicates the scenario of saving the residing companies. Point $\mathrm{C}$ is the last possible point of the cluster's evolutionary variability. 
It should be mentioned that the decline may start after any development phase (for example, in Fig. 7, the decline is missing not only after the maturity phase but also during the development phase). Researches indicated herein provide a more detail account of the causes $[14,15]$.

Summing up, I can point out the following phases in the cluster structure as indicated in Fig. 7.

1. Preliminary preparation with the focus on synergy (Section 1-2).

\section{Creation (Point 2).}

3. Adaptation (Section 2-3).

4. Development.

4.1. Pre-synergistic growth (Section 3-4).

4.2. Synergistic growth (Section 4-5).

5. Maturity.

\subsection{Storming (Section 5-10).}

5.2. Stagnation (Section 5-6).

6. Return to development (Section 8-9).

7. Decline.

\subsection{Transformation (Section 10-11).}

\subsection{Reemergence (Section 10-12).}

\subsection{Dissolution.}

7.3.1. Preservation of the cluster-based companies (Section 10-12-13).

7.3.2. Dissolution of the cluster-based companies (Section 10-14, 15-16).

It is important to understand that the above phases are not linear with respect to each other. Thus, the cluster may get to the dissolution phase not only from the stagnation, but also from storming, growth and adaptation.

Analyzing the phases, I conclude that neither of the phases is an even and linear section. Hence, the cluster may demonstrate the different pace of development (pre-synergistic and synergistic growth, return to maturity, storming, return to development) or decline (adaptation, stagnation, transformation, reemergence, dissolution).

Therefore, Fid. 7 displays key phases (preliminary preparation, creation, adaptation, development, maturity, decline), their interim phases (pre-synergistic growth, synergistic growth, storming, stagnation, transformation, reemergence), and variability points (points 4, 5, 8, 12). The cluster will definitely be a greater success, if it manages to return to its development during its maturity phase, while declines entail transformations.

In the mean time, the substance of the cluster development process can be comprehended through some structural and psychological aspects (research referred to herein [16] explains the importance of admitting the relationship of economy and psychology). For this, I suggest applying the Cynefin framework proposed by D. Snowden. The Cynefin framework offers four types of systems.

1. Chaotic systems without the cause-and-effect relationships. It is impossible to make assumptions and conclusions in such systems.

2. Complicated systems without the cause-and-effect relationships. Even if the system is exposed to two identical effects, it may generate the different outcome.

3. Complex systems where some experts do identify the cause-and-effect relationships.

4. Obvious (simple) systems with the cause-and-effect relationships.

Being initially in the first context, the system can morph into any phase so that it unavoidably passes through all the phases preceding the current one ${ }^{2}$ [17]. For example, the system will exist in contexts 1,2 and 3 within a certain period of time to get to context 4 .

The Cynefin framework can be compared with the model proposed herein. During the preliminary preparation, creation and adaptation, pre-synergistic growth (section 1-4 in Fig. 7), transformation (section 10-11) and reemergence (section 10-12), the regional innovative cluster is very likely to be chaotic. Hence, the business leader should have crisis management skills to tackle such a situation at this phase [18].

Fig. 7 gives a view of complicated systems at the sections of synergistic growth (section 4-5) and return to development (section 8-9). At these phases, the business leader should be flexible and strive to aid the cluster-based companies to agree upon tactic plans and methods of internal and external integration.

\footnotetext{
${ }^{2}$ Snowden D. Liberating Knowledge, in Liberating Knowledge. CBI Business Guide. London, Caspian Publishing, 1999.
} 
Complex systems may correspond with the maturity phase in its different forms, i.e. storming (section 5-10), stagnation (section 5-6). Under such circumstances, the business leader should be conversant with the classical management model (development and implementation of high-end strategies, key decision-making, etc.).

However, the cluster cannot turn into the obvious (simple) model since there always exist or will arise new implicit cause-and-effect relationships and the extent to which the cluster depends on such relationships can be evaluated by experts.

In this respect, there we can note an unobvious consequence implying the regular rotation of leaders at each of the above development phases, or their timely retraining in accordance with changes, or the initial appointment of a versatile professional to lead the cluster who would embody all these things.

Furthermore, it is important to strongly motivate the cluster leader and provide all necessary levers to encourage his/her subordinates (the aspects are described in detail in the research referred to herein [19]).

I made the following findings in this research. First, I pointed out a new phase when the cluster returns to development, which means that the mature cluster can reassume an explosive growth. Second, the decline phase has three possible scenarios, i.e. transformation, reemergence and dissolution. Third, I explained that the cluster development is not linear. Actually, I illustrate that there is no definite sequence of the cluster's life cycle phases. They can morph into each other as a result of multiple combinations. Forth, the cluster should not strive to level off during the maturity phase. If it levels off, it will definitely decline soon. Therefore, the cluster undergoes the phase of growth or decline. In other words, as per the model, the cluster cannot remain stable. It constantly passes phases of growth (at different pace) or decline (with different intensity). Furthermore, the research introduces the concept of evolutionary variability points of regional innovative clusters. Such points open up alternative scenarios of the cluster development. What is more, the model accommodates for psychological and professional traits of business leaders, which they may need at different development phases of the regional innovation cluster.

The research into the life cycle of regional innovation clusters can prove useful when such clusters are designed and created, guiding their development. Detailed description of each interim phase helps understand more profoundly how the region and respective regional innovative cluster are integrated. Regional authorities get a better knowledge of moments when their aid may be most effective for the cluster, how regional authorities' decisions can influence the development of the innovative cluster (inhibit or spur its growth).

If the most effective phases are determined (when the cluster may generate the highest benefits for the region), this will streamline the cooperation of the cluster and region. The article sets out respective mechanisms and levers to facilitate the process. For example, the region does not have a direct impact on pioneering companies upon their origination. However, it can prepare the cluster infrastructure. The thorougher the strategic planning of the regional industrial cluster, the more successful the cluster development. During the adaptation and pre-synergistic growth, the region should support the cluster as much as possible. If the regional innovative cluster is already mature, the region may expect the greatest benefits from the cluster and continue to support it. If the region provides the aid to the cluster substantially, the cluster is very likely to reassume its development and subsequently improve its productivity as compared with the storming phase. If the cluster declines, the region can help (or force in certain cases) configure the conditions for the decline (transformation, reemergence or dissolution). 


\section{Figure 1}

Common development phases of regional innovation clusters

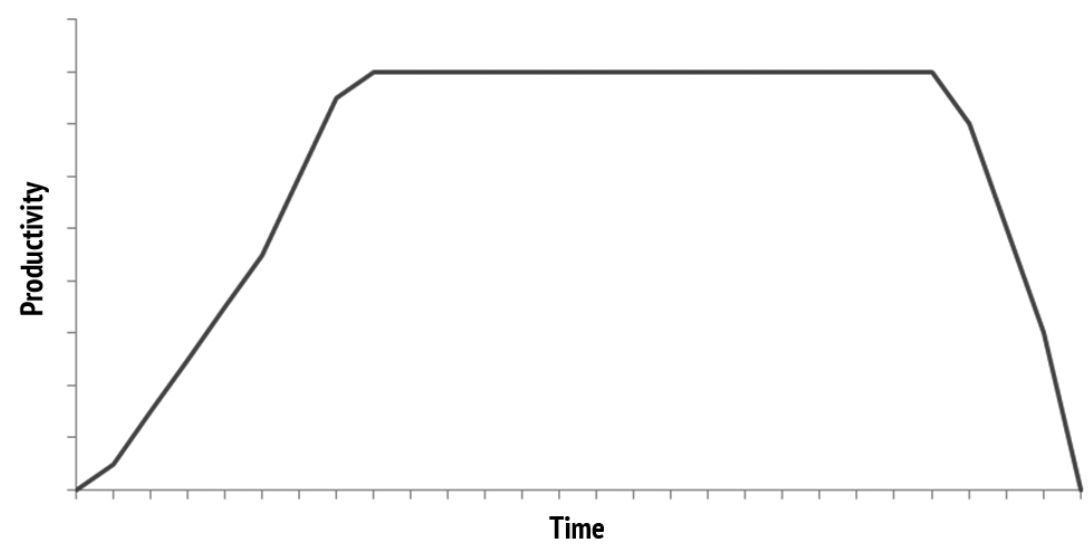

Source:Authoring

\section{Figure 2}

The team efficiency curve during the formation and development of the team

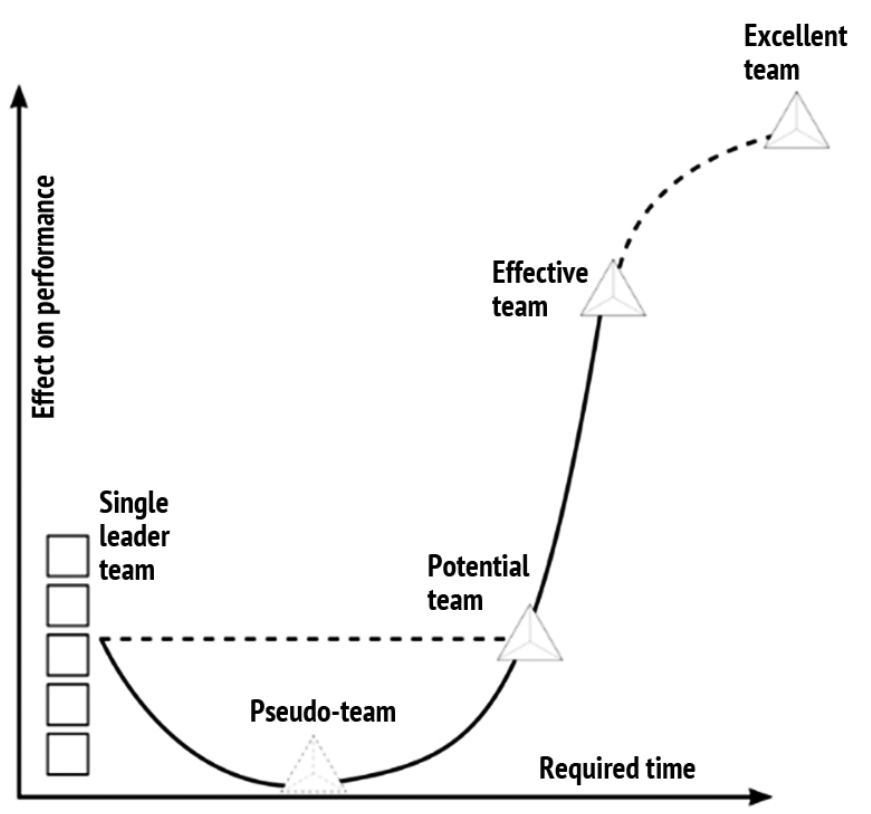

Source:Authoring 


\section{Figure 3}

The cluster performance curve at the stage of formation and development

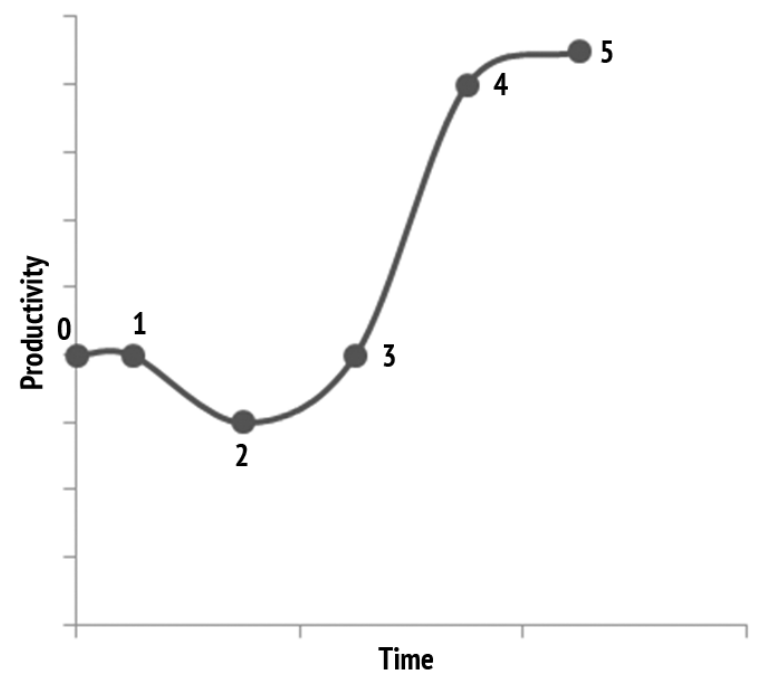

Source:Authoring

\section{Figure 4}

Alternative maturity options for a regional innovation cluster

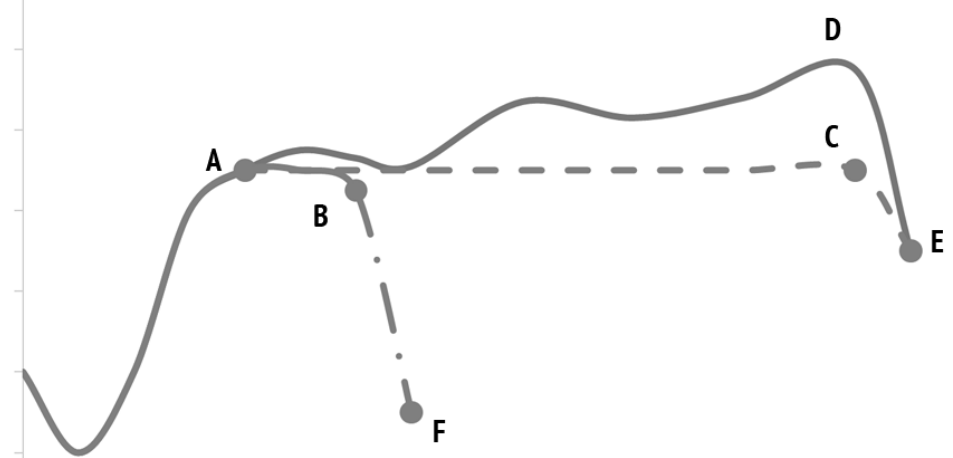

Source:Authoring

Please cite this article as: Nikolaev D.A. Specifying the Life Cycle Phases of Regional Innovation Clusters. Digest Finance, 2019, vol. 24, iss. 1, pp. 42-52. 


\section{Figure 5}

Return to growth

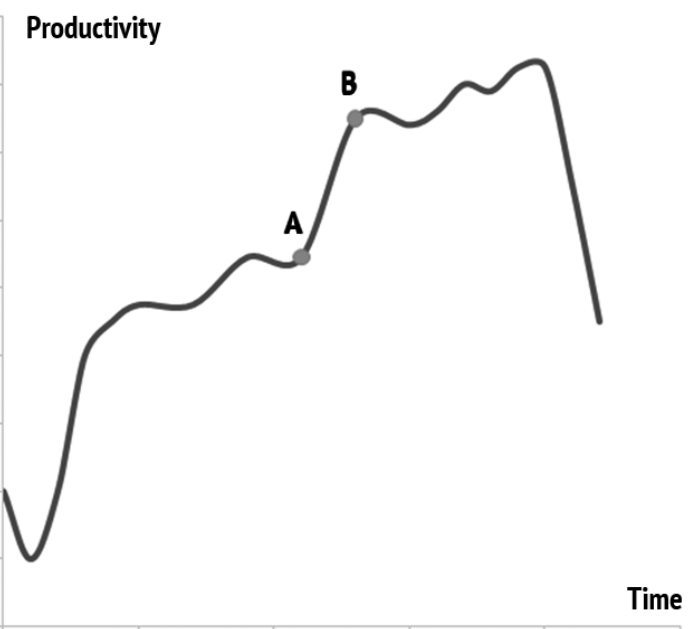

Source:Authoring

\section{Figure 6}

Restructuring of the regional innovation cluster

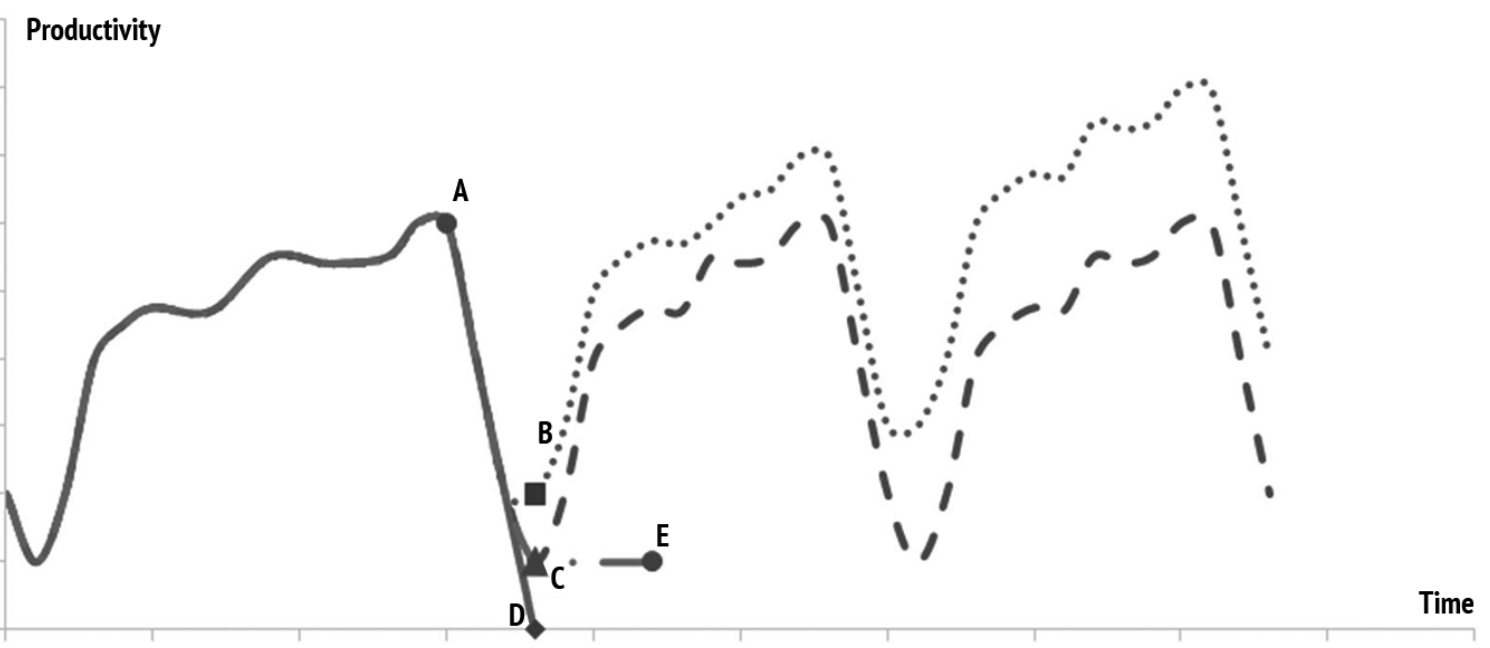

Source:Authoring 


\section{Figure 7}

\section{Evolutionary variability of the regional innovation cluster}

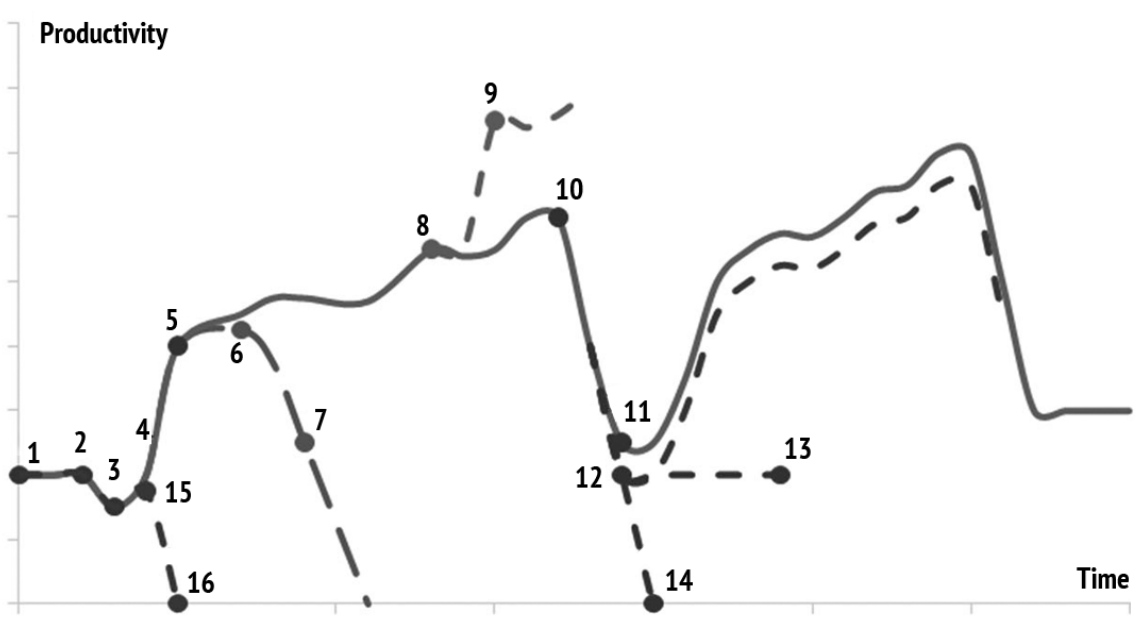

Source:Authoring

\section{References}

1. Petukhov R.N. [Analysis of world experience in the formation of territorial innovation clusters]. Molodoi uchenyi = Young Scientist, 2016, no. 16, pp. 191-194. (In Russ.)

2. Manushin D.V. [Estimation of the anti-crisis plan of the Russian government for 2015 and measures for its improvement]. Aktual'nye problemy ekonomiki i prava = Actual Problems of Economics and Law, 2015, no. 3, pp. 45-54. URL: https://cyberleninka.ru/article/v/otsenka-antikrizisnogo-plana-rossiyskogo-pravitelstva-na2015-god-i-vyrabotka-mer-po-ego-uluchsheniyu (In Russ.)

3. Manushin D.V. [The crisis management plan of the Russian Government of January 19, 2017: Views, prospects and improvement measures]. Natsional'nye interesy: prioritety i bezopasnost' = National Interests: Priorities and Security, 2017, vol. 13, iss. 12, pp. 2291-2311. (In Russ.) URL: https://doi.org/10.24891/ni.13.12.2291

4. Manushin D.V. [Real causes of global economic crises and their impact on the Russian economy]. Finansy $i$ kredit = Finance and Credit, 2014, no. 42, pp. 52-70. URL: https://cyberleninka.ru/article/v/istinnye-prichinymirovyh-ekonomicheskih-krizisov-i-ih-vozdeystvie-na-rossiyskuyu-ekonomiku (In Russ.)

5. Manushin D.V. [Anti-crisis state management of Russia's technological development]. Aktual'nye problemy ekonomiki i prava = Actual Problems of Economics and Law, 2015, no. 1, pp. 67-74.

URL: https://cyberleninka.ru/article/v/antikrizisnoe-gosudarstvennoe-upravlenie-tehnologicheskim-razvitiemrossii (In Russ.)

6. Manushin D.V. [Updating the essence of tax controversy and the measures to mitigate it under crisis: Fighting the shadow economy and the transition to fair taxation rules]. Mezhdunarodnyi bukhgalterskii uchet = International Accounting, 2018, vol. 21, iss. 1, pp. 103-120. (In Russ.) URL: https://doi.org/10.24891/ia.21.1.103

7. Katzenbach D., Smith D. Komandnyi podkhod: Sozdanie vysokoeffektivnoi organizatsii [The Wisdom of Teams: Creating the High-Performance Organization]. Moscow, Al'pina Pablisher Publ., 2017, 376 p.

8. Kireeva A.A. [Theoretical and methodological framework establishing the conditions for the development of innovation clusters]. Ekonomicheskie $i$ sotsial'nye peremeny: fakty, tendentsii, prognoz = Economic and Social Changes: Facts, Trends, Forecast, 2014, no. 1, pp. 182-189.

URL: https://cyberleninka.ru/article/v/teoretiko-metodologicheskie-osnovy-formirovaniya-usloviy-razvitiyainnovatsionnyh-klasterov (In Russ.) 
9. Frolkin D.V. [The algorithm of formation of informational cluster]. Izvestiya Saratovskogo universiteta. Novaya seriya. Seriya Ekonomika. Upravlenie. Pravo = Izvestiya of Saratov University. New Series. Series: Economics. Management. Law, 2013, vol. 13, no. 4-2, pp. 687-691. (In Russ.)

10. Mal'gin V.A., Kramin T.V., Alpatova E.S. et al. Problemy integratsii real'nogo i finansovogo sektorov ekonomiki Rossii [Integration issues of real and financial sectors of Russia's economy]. Kazan, Poznanie Publ., 2012, 200 p.

11. Zaika A.A. [Notes of life clusters]. Mir novoi ekonomiki = The World of New Economy, 2010, no. 4, pp. 15-17. (In Russ.)

12. Spitsyn V.V. [Creation and evolution local high-tech clusters: foreign experience]. Vestnik Tomskogo gosudarstvennogo universiteta = Tomsk State University Journal, 2007, no. 302, pp. 181-185.

URL: https://cyberleninka.ru/article/v/sozdanie-i-razvitie-lokalnyh-vysokotehnologichnyh-klasterovzarubezhnyy-opyt (In Russ.)

13. Rovin D.A. [World experience of free economic zones on the example of Dalian]. Nauchnyi al'manakh= Science Almanac, 2017, no. 6-1, pp. 93-97. (In Russ.)

14. Rozanova N.M., Kostenko E.D. [Innovative clusters and public administration: Market failures vs government failures]. Terra Economicus, 2014, vol. 12, no. 1, pp. 41-52. (In Russ.)

15. Menzel M.-P., Fornahl D. Cluster Life Cycles - Dimensions and Rationales of Cluster Evolution. Industrial and Corporate Change, 2010, vol. 19, iss. 1, pp. 205-238. URL: https://doi.org/10.1093/icc/dtp036

16. Grigor'eva O.V., Yakovleva E.L., Grigor'eva N.S. et al. Ekonomicheskaya psikhologiya: nauchnye ocherki [Economic psychology: Scholarly essays]. Kazan, Poznanie Publ., 2016, 200 p.

17. Snowden D.J., Boone M.E. A Leader's Framework for Decision Making. Harvard Business Review, 2007, no. 11, pp. 69-76.

18. Ritchie B.W. Chaos, Crises and Disasters: A Strategic Approach to Crisis Management in the Tourism Industry. Tourism Management, 2004, vol. 25, iss. 6, pp. 669-683. URL: https://doi.org/10.1016/j.tourman.2003.09.004

19. Manushin D.V. [Motivation of Russian jobholders during crisis: Assessment and the issues of management]. Natsional'nye interesy: prioritety $i$ bezopasnost' = National Interests: Priorities and Security, 2016, vol. 12, iss. 7, pp. 17-35. URL: https://cyberleninka.ru/article/v/otsenka-i-upravlenie-problemami-motivatsiirossiyskih-gosudarstvennyh-sluzhaschih-v-usloviyah-krizisa (In Russ.)

\section{Conflict-of-interest notification}

I, the author of this article, bindingly and explicitly declare of the partial and total lack of actual or potential conflict of interest with any other third party whatsoever, which may arise as a result of the publication of this article. This statement relates to the study, data collection and interpretation, writing and preparation of the article, and the decision to submit the manuscript for publication. 